\title{
Perubahan Luasan Vegetasi Mangrove di Desa Bedono Kecamatan Sayung Kabupaten Demak Tahun 2009 dan 2019 Menggunakan Citra Satelit Landsat
}

\author{
Wisnu Adjie Pramudito*, Jusup Suprijanto, Nirwani Soenardjo \\ Departemen IImu Kelautan, Fakultas Perikanan dan IImu Kelautan, Universitas Diponegoro \\ JI. Prof. H. Soedarto S.H, Tembalang,Semarang, Jawa Tengah 50275 Indonesia \\ *Corresponding author, e-mail : wisnuwap@gmail.com
}

\begin{abstract}
ABSTRAK: Hutan Mangrove merupakan salah satu ekosistem vegetasi yang berada di wilayah pasang surut di pesisir, pantai dan pulau-pulau kecil. Pantai utara Jawa merupakan salah satu wilayah yang memiliki ekosistem mangrove yang mengalami perubahan cukup signifikan. Pertambahan luasan vegetasi mangrove di desa Bedono dapat diamati dengan menggunakan citra dari satelit landsat. Tujuan dari penelitian ini adalah untuk mengetahui perubahan luas lahan mangrove yang terjadi di kawasan pesisir Desa Bedono, Kecamatan Sayung, kabupaten Demak Tahun 2009 dan 2019. Metode yang diaplikasikan dalam penelitian dengan menggunakan metode deskriptif eksploratif, metode yang memiliki tujuan yaitu melakukan pemecahan masalah yang digali secara luas tentang sebab-sebab atau hal-hal yang mempengaruhi terjadinya sesuatu berdasarkan fakta-fakta yang terjadi di lapangan. Untuk kegiatan groundcheck menggunakan metode sampling kuadrat yaitu membuat plot berukuran 10x10 m untuk kategori pohon yang di dalamnya terdapat subplot $5 \times 5 \mathrm{~m}$ untuk kategori sapling dan $1 \times 1 \mathrm{~m}$ untuk kategori seedling. Hasil penelitian menunjukkan pertambahan luas lahan mangrove di Desa Bedono selama rentang waktu tahun 2009 - 2019, pada tahun 2009 sebesar 122.58 ha dan pada tahun 2019 sebesar 197.19 ha . luas vegetasi dalam kurun waktu tersebut mengalami pertambahan luas sebesar 74.76 ha. kerapatan di titik stasiun 1 memiliki kerapatan sebesar 3633 ind/ha, sementara di titik stasiun 2 dan 3 masing masing sebesar $3700 \mathrm{ind} / \mathrm{ha}$ dan $3500 \mathrm{ind} / \mathrm{ha}$. Tiga spesies mangrove yang dapat ditemukan di kawasan mangrove desa Bedono adalah Avicennia marina, Avicennia alba, dan Rhizopora mucronata.
\end{abstract}

Kata Kunci : Avicennia Marina; Landsat; Mangrove; Bedono

\section{The Changes of Mangrove Vegetation Area in the Bedono Village Sayung District of Demak Regency Using Landsat Satellite Imagery in 2009 and 2019}

ABSTRACT: Mangrove forest is one of the vegetation ecosystems in the tidal areas on the coast, beaches and small islands. The north coast of Java is one of the regions that has a significant change in mangrove ecosystems. Changes in the extent of mangrove vegetation in the village of Bedono can be observed using imagery from the Landsat satellite. The purpose of this study was to assess changes occurred mangrove vegetation in coastal areas Bedono Village, District Sayung, Demak district in 2009 and 2019. The method applied in research using exploratory descriptive method, a method which has the goal of solving the problem are explored extensively on the causes or matters affecting the occurrence of something based on facts on the ground. For groundcheck activity using sampling methods squares that make plots measuring $10 \times 10 \mathrm{~m}$ for the category tree in which there are subplots $5 \times 5 \mathrm{~m}$ for category sampling and $1 \times 1 \mathrm{~m}$ for category seedling. The results showed an increase in the area of mangrove land in the village of Bedono during the span of years 2009-2019, in 2009 amounted to 122.58 ha and in 2019 amounted to 197.19 ha the area of vegetation in this period experienced an increase in area of 74.76 ha. density at station 1 has a density of 3633 ind/ha, while at station 2 and 3 points respectively 3700 ind/ha and 3500 ind/ha. Mangrove species that can be found in the mangrove area of Bedono village are Avicennia marina, Avicennia alba, and Rhizopora mucronata.

Keywords: Avicennia marina; Landsat; Mangrove; Bedono. 


\section{PENDAHULUAN}

Hutan Mangrove merupakan salah satu ekosistem vegetasi yang berada di wilayah pasang surut di pesisir, pantai dan pulau-pulau kecil. Keberadaan hutan mangrove layaknya satu mata rantai yang tidak dapat dipisahkan dengan ekosistem lainnya, yaitu ekosistem vegetasi hutan pantai dan terumbu karang. Tingkat kerusakan ekosistem mangrove di Indonesia, termasuk Jawa Tengah sangat cepat akibat pembukaan lahan tambak, penebangan hutan mangrove dan pencemaran lingkungan perubahan luasan mangrove di Kabupaten Demak juga mengalami penurunan sekitar 8\%-10\% sejak tahun 1980 begitu pula di Mimika, Papua karena adanya alih fungsi lahan mangrove oleh masyarakat untuk alih fungsi menjadi tambak udang. (Chafid et al., 2012; Fajri et al., 2012; Pratiwi et al., 2014). .

Menurut data dari Dinas Kelautan dan Perikanan Kabupaten Demak, pada tahun 2011 ekosistem mangrove di Kabupaten Demak sekitar 8 \% dalam kondisi rusak. Rusaknya hutan mangrove turut menyebabkan wilayah daratan di sekitar pesisir Kabupaten Demak memiliki pertahanan yang lemah terhadap dinamika alam yang berasal dari arah laut, seperti arus, gelombang, pasang surut, dan angin Desa Bedono yang terletak di Kecamatan Sayung Kabupaten Demak merupakan salah satu wilayah di pesisir Kabupaten Demak yang memiliki ekosistem mangrove.

Pertambahan luasan vegetasi mangrove di desa Bedono dapat diamati dengan menggunakan beberapa metode, Dewanti et al., (1998) menjelaskan bahwa citra landsat +ETM memiliki kemampuan untuk mendeteksi vegetasi dan kemudian ketersediaan data citra time series yang cukup meliputi seluruh wilayah Indonesia, gratis dan resolusi (spasial, temporal, radiometrik) cukup baik (tingkat menengah) merupakan tiga keunggulan yang dimiliki sekaligus oleh citra landsat. Hal ini mendasari dilakukannya penelitian ini yang dimaksudkan untuk mengetahui bagaimana perubahan vegetasi mangrove di desa Bedono dan bagaimana kerapatan vegetasinya dengan menggunakan citra landsat pada tahun 2009 dan 2019.

Penelitian ini memiliki manfaat yaitu untuk mengetahui berapa perubahan luasan dari mangrove di Desa Bedono dan mengetahui berapa kerapatan vegetasi dari luasan lahan mangrove di Desa Bedono. Manfaat lain dari penelitian ini adalah untuk mempermudah kegiatan monitoring yang bertujuan untuk menjaga luasan mangrove yang dimaksudkan dan untuk menjaga ekosistem vegetasi pesisir pantai agar luasannya tidak semakin berkurang.

\section{MATERI DAN METODE}

Materi penelitian yang digunakan dalam penelitian ini adalah data citra landsat vegetasi mangrove yang berada di desa Bedono kecamatan Sayung kabupaten Demak provinsi Jawa Tengah. Citra Satelit Landsat-7 digunakan untuk perekaman pada tahun 2009 karena teknologi yang mendukung perekaman baru berkembang ke generasi Landsat-7. Sementara untuk perekaman tahun 2015, 2017, dan 2019, digunakan Landsat-8 karena teknologi perekaman citra sudah berkembang ke generasi Landsat ke-8. Penelitian ini mengaplikasikan metode Normalized Difference Vegetation Index (NDVI)

Tahap selanjutnya yakni pengolahan data penginderaan jauh, penentuan titik lokasi Groundcheck. Metode yang diaplikasikan dalam penelitian ini adalah dengan menggunakan metode deskriptif eksploratif, yaitu metode yang memiliki tujuan yaitu melakukan pemecahan masalah yang digali secara luas tentang sebab-sebab atau hal-hal yang mempengaruhi terjadinya sesuatu berdasarkan fakta-fakta yang terjadi di lapangan. Tujuan koreksi ini adalah mengurangi pengaruh kesalahan nilai kecerahan gambar yang dapat membatasi kemampuan seseorang untuk menafsirkan atau memproses secara kuantitatif dan menganalisis citra (Aryastana et al., 2017).

Pengolahan citra satelit menggunakan software Ermapper 7.0 dan ArcGis 10.5. tahap pertama penggabungan tiap pixel dari band-band menjadi suatu citra baru yang bisa digunakan. Koreksi radiometrik adalah proses untuk meningkatkan suatu kecerahan dan ketajaman citra. Tahap selanjutnya koreksi geometrik, koreksi geometrik adalah untuk menghilangkan distorsi geomterik pada citra yang sudah dapat diperkirakan seperti pengaruh sistem optik yang digunakan. Tahap peningkatan kualitas citra merupakan salah satu proses awal dalam peningkatan mutu citra. Citra landsat $7+$ ETM mengalami masalah pada Scan Line Corrector 
(SLC) sehingga mengakibatkan adanya garis-garis hitam (kerusakan data) pada citra. yang menyebabkan hasil perekaman citranya tidak sempurna (Striping). Gap fill adalah metode yang didasarkan pada penerapan metode geostatistik multi-titik Pengambilan Sampel Langsung. . Metode ini menggunakan resampling stokastik bersyarat area yang diketahui dalam gambar pelatihan untuk mensimulasikan lokasi yang tidak diketahui (Gaohong et al., 2016). Citra tahun 2009 dilakukan gap fill antara citra perekaman bulan Mei 2009 dan bulan Oktober 2009. . Dalam penelitian ini klasifikasi yang dilakukan adalah tipe Supervised, yaitu kategori objek-objek yang terkandung pada citra telah dapat diidentifikasi. Dalam hal ini, objek yang diklasifikasi adalah vegetasi mangrove.

Dalam membedakan objek vegetasi mangrove dengan vegetasi jenis lain (non-mangrove) digunakan anlisis NDVI. Dengan transformasi NDVI tersebut, vegetasi mangrove akan terlihat lebih kontras dengan proporsi tingkat kecerahan yang lebih tinggi. Hal ini dikarenakan dalam pemanfaatan NDVI menggunakan gelombang NIR dan gelombang $R$ dimana gelombang NIR sangat peka akan klorofil vegetasi. Berikut adalah algoritma perhitungan NDVI:

$$
N D V I=\frac{(N I R-R E D)}{(N I R+R E D)}
$$

Keterangan: NDVI : Normalized Difference Vegetatiion Index; NIR : Band infra merah dekat (Near Infra-Red); RED : Band merah

Nilai NDVI berkisar dari -1 sampai dengan 1 dengan klasifikasi -1 sampai 0 termasuk ke dalam kelompok bukan vegetasi dan 0 sampai dengan 1 termasuk kelompok vegetasi. Untuk kerapatan vegetasi, nilai NDVI -1 s/d 0,32 menunjukkan tingkat kerapatan vegetasi jarang, Nilai NDVI 0,33 s/d 0,42 menunjukan tingkat kerapatan vegetasi sedang, dan nilai NDVI 0,43 s/d 1 menunjukkan tingkat kerapatan vegetasi rapat (Departemen Kehutanan, 2003). Tahap selanjutnya adalah groundcheck hasil interpretasi pemetaan awal dari citra satelit untuk dibandingkan dengan data di lapangan pada titik yang telah ditentukan, yaitu sebanyak 3 stasiun dan 9 titik pengambilan data. Pengambilan data lapangan tersebar di Desa Bedono Kecamatan Sayung Kabupaten Demak. Untuk data vegetasi mangrove sendiri, setiap titik pengambilan diukur 3 fase mangrove yaitu Pohon (tree) dengan $\varnothing$ (diameter) $\geq 4 \mathrm{~cm}$, Sappling $1 \mathrm{~cm} \leq \varnothing \leq 4 \mathrm{~cm}$ dan seedling dengan $\varnothing$ $\leq 1 \mathrm{~cm}$. Untuk transek yang digunakan dalam pengukuran data vegetasi mangrove ini dibagi menjadi 3 kategori, yaitu untuk kategori pohon dengan luas transek $10 \times 10 \mathrm{~m}$, kategori sappling dengan luas $5 \times 5 \mathrm{~m}$, dan kategori Seedling dengan luas $2 \times 2 \mathrm{~m}$.

\section{HASIL DAN PEMBAHASAN}

Desa Bedono merupakan salah satu desa pesisir di Kecamatan Sayung, Kabupaten Demak dengan kondisi topografi yang landai dan datar ini mengalami kerusakan pantai akibat erosi, alih fungsi lahan pelindung pantaidan pencemaran perairan pantai. Kerusakan ini disebabkan oleh faktor alam maupun aktifitas manusia. Areal mangrove di desa Bedono kecamatan Sayung kabupaten Demak memiliki potensi dan permasalahan. Keberadaan hutan mangrove di Desa Bedono memberikan manfaat baik secara ekonomis dan ekologis. Namun kondisi pesisir pantai desa Bedono mengalami kerusakan yang disebabkan oleh perubahan alih fungsi lahan mangrove menjadi tambak udang terutama di tahun 1980, mengakibatkan timbulnya abrasi di sebagian besar pesisir desa Bedono.

Pada tahun 2009, luasan mangrove dengan kelas NDVI jarang memiliki luasan sebesar $58.74 \mathrm{Ha}$. luasan mangrove dengan kelas NDVI sedang memiliki luasan sebesar $31.19 \mathrm{Ha}$ dan luasan mangrove dengan kelas NDVI padat memiliki luasan sebesar $32.64 \mathrm{Ha}$ Berdasarkan interpretasi ini, Desa Bedono tahun 2009 memiliki luasan mangrove sebesar 122.58 ha. Pada tahun 2019, luasan mangrove dengan kelas NDVI jarang memiliki luasan 56.98 ha. Luasan mangrove dengan kelas NDVI sedang memiliki luasan sebesar 37.69 ha dan luasan mangrove dengan kelas NDVI padat memiliki luasan sebesar 102.51 ha. Berdasarkan interpretasi ini, desa Bedono tahun 2019 memiliki luasan mangrove sebesar 197.19 ha.

Dari gambar 1 didapatkan perubahan vegetasi mangrove dari tahun 2009 dan 2019 yang 
didapatkan dari interpretasi citra landsat. Warna merah mewakili kelas mangrove rapat dengan nilai NDVI >0,42 s.d 1. Warna oranye mewakili kelas mangrove sedang dengan nilai NDVI 0,32 s.d 0,42 dan warna kuning mewakili kelas NDVI jarang dengan nilai NDVI -1 s.d 0,32. Sementara warna hijau mempresentasikan tidak ada vegetasi yang terdeteksi. Nilai NDVI ini Berdasarkan acuan dari Departemen Kehutanan tahun 2003.

Pada hasil studi pengolahan citra landsat 7 +ETM dan citra landsat 8 pada tahun 2009, 2015, 2017, dan 2019 penambahan dan perubahan luasan vegetasi mangrove terjadi dikarenakan adanya program rehabilitasi mangrove oleh lembaga swadaya masyarakat dan dinas - dinas pemerintahan terkait. Hasil analisa citra landsat pada kurun waktu tahun 2009, 2015, 2017 hingga 2019 terjadi perubahan luasan vegetasi mangrove seperti yang tertera pada Gambar 2 dimana vegetasi mangrove tersebut bertambah ke arah daratan. Adanya pertambahan luas area mangrove di lokasi penelitian diduga karena lokasi penelitian merupakan kawasan rehabilitasi mangrove. perubahan tingkat kerapatan mangrove dari kerapatan jarang atau sedang menjadi lebat umumnya terjadi pada lokasi yang tumbuhnya secara alami. Citra Landsat 7 ETM diperlukan metode Gap Fill, yaitu metode yang dapat digunakan untuk mengisi daerah kosong pada data citra landsat dari data landsat lainnya. Transformasi linear diaplikasikan untuk mengisi citra, menyesuaikan berdasarkan standar deviasi dan nilai rerata tiap saluran.

\section{Analisa Struktur Vegetasi}

Berdasarkan hasil penelitian di desa Bedono kecamatan Sayung kabupaten Demak, ditemukan 3 spesies pada masing masing stasiun dimana yang menjadi komponen utama vegetasi mangrove di wilayah ini, diantaranya komponen mayor famili Avicenniaceae dan famili Rhizoporaceae. Spesies yang ditemukan dari famili tersebut adalah Avicennia marina, Avicennia alba dan Rhizopora mucronata. Pada kategori pohon, terdapat nilai kerapatan tertinggi pada

Tabel 1. Tabel luasan perubahan mangrove

\begin{tabular}{ccccccc}
\hline \multicolumn{2}{c}{\begin{tabular}{c} 
Kelas NDVI \\
\multicolumn{2}{c}{ Mangrove }
\end{tabular}} & \multicolumn{2}{c}{ Tahun 2009 } & \multicolumn{2}{c}{ Tahun 2019 } & \multirow{2}{*}{ Perubahan Luasan (ha) } \\
\cline { 2 - 5 } & pixel & Luas (ha) & pixel & Luas (ha) & \\
\hline Jarang & 1 & 1233 & 58.74 & 1082 & 56.98 & -1.76 \\
Sedang & 2 & 736 & 31.19 & 1215 & 37.69 & +6.5 \\
Padat & 3 & 637 & 32.64 & 1812 & 102.51 & +69.87 \\
\multicolumn{2}{c}{ Total } & 2606 & 122.58 & 4109 & 197.19 & 74.61 \\
\hline
\end{tabular}

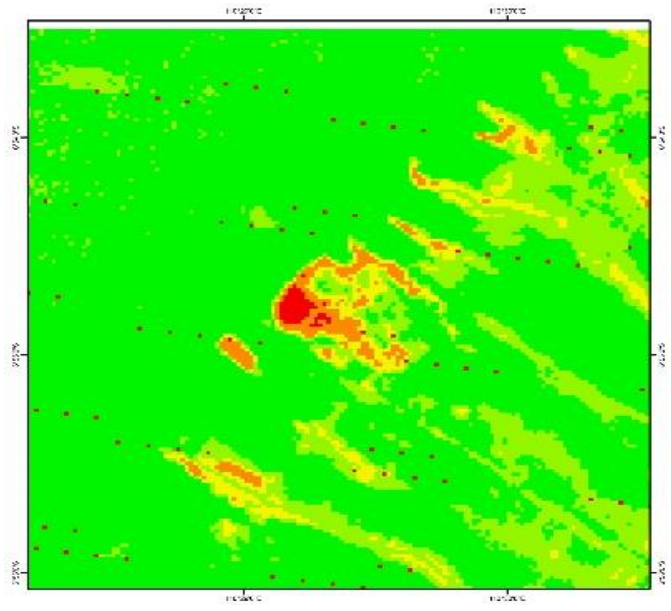

Citra NDVI tahun 2009

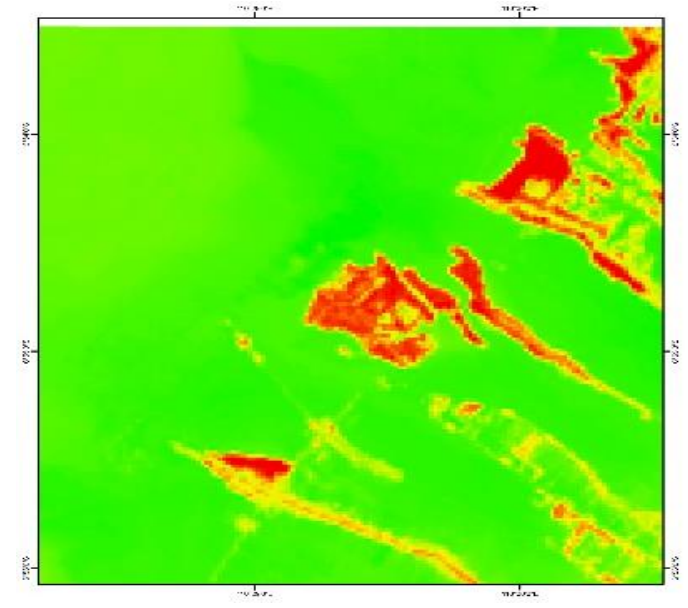

Citra NDVI tahun 2019

Gambar 1. Hasil Interpretasi Citra Perubahan NDVI mangrove pada tahun 2009 dan 2019 


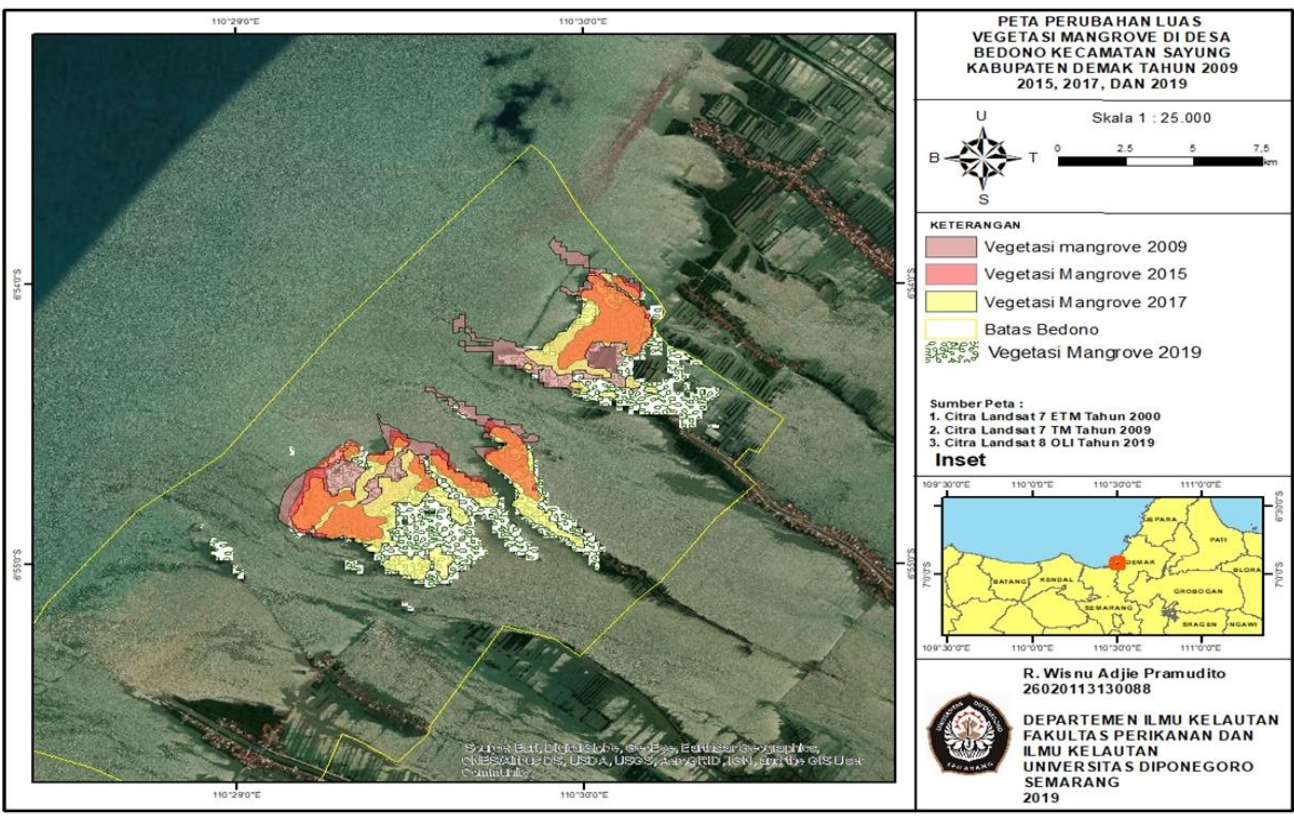

Gambar 2. Peta Perubahan Luas Vegetasi Mangrove Tahun 2009, 2015, 2017, Dan 2019

Tabel 2. Hasil analisis data kerapatan jenis vegetasi mangrove (ind/ha) kategori pohon di setiap stasiun pengambilan data

\begin{tabular}{cccc}
\hline \multirow{2}{*}{ Jenis Mangrove } & \multicolumn{3}{c}{ Stasiun Pengambilan Data } \\
\cline { 2 - 4 } Avicennia alba & 1 & 2 & 3 \\
Avicennia marina & 3067 & 0 & 100 \\
Rhizophora mucronata & 566.67 & 1467.00 & 3400 \\
Jumlah & 0 & 2233.00 & 0 \\
& 3633 & 3700 & 3500 \\
\hline
\end{tabular}

Tabel 3. Hasil analisis data kerapatan jenis vegetasi mangrove (ind/ha) kategori sapling (anakan) di setiap stasiun pengambilan data

\begin{tabular}{cccc}
\hline Jenis Mangrove & \multicolumn{3}{c}{ Stasiun Pengambilan Data } \\
\cline { 2 - 4 } & 1 & 2 & 3 \\
\hline Avicennia alba & 5000 & 0 & 11000 \\
Avicennia marina & 220000 & 190000 & 150000 \\
Rhizophora mucronata & 530000 & 280000 & 0 \\
Jumlah & 755000 & 470000 & 161000 \\
\hline
\end{tabular}

Tabel 4. Hasil analisis data kerapatan jenis vegetasi amngrove (ind/ha) kategori seedling (bibit) di setiap stasiun pengambilan data.

\begin{tabular}{cccc}
\hline \multirow{2}{*}{ Jenis Mangrove } & \multicolumn{3}{c}{ Stasiun Pengambilan Data } \\
\cline { 2 - 4 } & 1 & 2 & 3 \\
\hline Avicennia alba & 0 & 0 & 533 \\
Avicennia marina & 4800.00 & 3467 & 5318.00 \\
Rhizophora mucronata & 0 & 2933 & 1067.00 \\
Jumlah & 4800 & 6400 & 6918 \\
\hline
\end{tabular}


stasiun 2 dengan nilai kerapatan sebesar 3700 ind/Ha. spesies yang mendominasi pada kategori pohon adalah spesies Rhizpora mucronata, hal ini diduga spesies tersebut merupakan hasil dari rehabilitasi dari tahun tahun sebelumnya yang dilakukan oleh dinas kelautan perikanan kabupaten demak dan instansi lainnya.

Kerapatan tertinggi di tingkat pohon terdapat di stasiun 2 dengan nilai kerapatan sebesar $3700 \mathrm{ind} / \mathrm{ha}$. dengan spesies tertinggi adalah Rhizopora mucronata dengan nilai kerapatan sebesar $2233 \mathrm{ind} / \mathrm{ha}$. Kerapatan tertinggi di tingkat anakan/Sapling di semua stasiun didominasi oleh spesies Avicennia marina yang terdapat di semua stasiun pengambilan data. Nilai Kerapatan tertinggi berada di stasiun 3 dengan nilai 6918 ind/ha dengan spesies yang mendominasi yaitu spesies Avicennia marina dengan nilai 5318 ind/ha. Data yang diperoleh dari pengamatan di tingkat pohon dapat dikategorikan baik dan sangat padat berdasarkan Kepmen LH no. 201 tahun 2004 dengan nilai kerapatan $\geq 2500$ ind/ha

\section{KESIMPULAN}

Hasil penelitian menunjukkan pertambahan luas lahan mangrove di Desa Bedono selama rentang waktu tahun 2009 - 2019, pada tahun 2009 sebesar 122.58 ha dan pada tahun 2019 sebesar 197.19 ha . luas vegetasi dalam kurun waktu tersebut mengalami pertambahan luas sebesar 74.76 ha. kerapatan di titik stasiun 1 memiliki kerapatan sebesar 3633 ind/ha, sementara di titik stasiun 2 dan 3 masing masing sebesar $3700 \mathrm{ind} / \mathrm{ha}$ dan $3500 \mathrm{ind} / \mathrm{ha}$. 3.Spesies mangrove yang dapat ditemukan di kawasan mangrove desa Bedono adalah Avicennia marina, Avicennia alba, dan Rhizopora mucronata.

\section{DAFTAR PUSTAKA}

Aryastana, P., Ardantha, I., Agustini, A. \& Komang, N., 2017. Analisis perubahan garis pantai dan laju erosi di Kota Denpasar dan Kabupaten Badung dengan citra satelit SPOT. Jurnal Fondasi, 6(2):100-111.

Chafid, M.A., Pribadi, R. \& Suryo, A.A.D. 2012. Kajian Perubahan Luas Lahan Mangrove di Desa Bedono Kecamatan Sayung Kabupaten Demak Menggunakan Citra Satelit Ikonos Tahun 2004 dan 2009. Journal of Marine Research, 1(2):167-173.

Departemen Kehutanan, 2003. Pedoman Inventarisasi Dan Identifikasi Lahan Kritis Mangrove I. Jakarta: Badan Penelitian dan Pengembangan Kehutanan Departemen Kehutanan, hal 9

Fajri, Subardjo, P. \& Pribadi, R. 2012. Studi Perubahan Luasan Vegetasi Mangrove Menggunakan Citra Landsat TM dan Landsat 7 ETM+ Tahun 1998-2010 di Pesisir Kabupaten Mimika Papua. Journal of Marine Research, 1(1):146-155

Fikriyani, M. dan Mussadun. 2014. Evaluasi program rehabilitasi mangrove di pesisir desa Bedono Kecamatan Sayung kabupaten Demak. Jurnal Ruang, 2(1):81-90

Irsadi, A., Anggoro, S. \& Soeprobowati, 2019. Shoreline and Mangrove Analysis along SemarangDemak, Indonesia for Sustainable Environmental Management. Jurnal Pendidikan IPA Indonesia, 8(1):1-11.

Kementerian Lingkungan Hidup, 2004, Keputusan Menteri Lingkungan Hidup No. 201 tahun 2004 Tentang Kriteria Baku dan Pedoman Penentuan Kerusakan Mangrove, Jakarta : KLH.

Mueller-Dombois, D. \& Ellenberg, H. 1974 Aims and methods of vegetation ecology.

Pratiwi, D.V.N.I.N, Pribadi, R. \& Suryoputro, A.A.D. 2014, Kajian Perubahan Luas Mangrove Menggunakan Metode NDVI Data Citra Satelit Landsat 7 ETM+ dan Landsat 8 ETM Tahun 1999, 2003 dan 2013 di Pesisir Desa Berahan Kulon dan Desa Berahan Wetan Kecamatan Wedung, Demak. Journal of Marine Research, 3(4):650-657

Yin, G., Mariethoz, G. \& McCabe, M. 2016. Gap-Filling of Landsat 7 Imagery Using the Direct Sampling Method. Remote Sensing, 9(1):12. doi : 10.3390/rs9010012 